\title{
Corrigendum
}

\section{Distance Matters: Place, Political Legitimacy and Popular Support for European Integration}

\author{
Mabel Berezin and Juan Diez-Medrano \\ Comparative European Politics (2008) 6, 235. doi:10.1057/cep20084
}

\section{Correction to:}

Comparative European Politics (2008) 6, 1-32.

doi:10.1057/Palgrave.cep.6110119

The following acknowledgement section should have been published in this article in CEP 6.1. We apologize to the authors and to those mentioned in the acknowledgement for this omission.

\section{Acknowledgments}

We thank participants in the session on Transnational Sociology at the 2005 ASA Meetings in Philadelphia, PA. John Agnew, Nicholas Entrikin, Lisbet Hooghe, Peter Katzenstein and Sidney Tarrow made thoughtful comments on earlier versions of this paper. Akos Rona-Tas, Stephen Morgan, Kim Weeden, and Christopher Wlezien provided suggestions on methodology. Diez Medrano thanks participants in colloquia at the Department of Sociology, Cornell University, the Facultad de Ciencias Economicas y Empresariales, Universidad de Barcelona and European Studies Center at the University of Pennsylvania. We completed this article while Díez Medrano held the Luigi Einaudi Chair in European and International Studies at Cornell University. He gratefully acknowledges the support of the Institute for European Studies at Cornell.

Anna Karwowska designed our map. Alexa Yesukevich and Min-Dong Paul Lee provided careful editorial assistance. 